\title{
Self-triggering Streamer Chamber and Its Applications to Nuclear Physics(Abstract_要旨)
}

\section{$\operatorname{AUTHOR}(\mathrm{S})$ :}

Kobayashi, Shigeharu

\section{CITATION:}

Kobayashi, Shigeharu. Self-triggering Streamer Chamber and Its Applications to Nuclear Physics. 京都大学, 1971, 理学博士

\section{ISSUE DATE:}

\section{1-03-23}

URL:

http://hdl.handle.net/2433/213614

RIGHT: 


\section{【41 】}

氏 名

学位の種類 学位記 番号 学位授与の日付 学位授与の要件 研究科・専攻 学位論文題目
小林 茂 治

理学 博士

理 博 第 208 号

昭和 46 年 3 月 23 日

学位規 則第 5 条第 1 項該当

理学研究科物理学第二専攻

\section{Self-triggering Streamer Chamber and Its} Applications to Nuclear Physics

（自己作働型ストリーマ放電箱とその原子核実験への応用）

(主 查)

論文調查委員教授安見真次郎 教授小林晨作 教授 中井祥夫

\section{論文内容 の 要旨}

本論文は自己作働型ストリーマ放電箱（Self-triggering streamer chamber，以下 STSC 之略す）の開 発研究に関するものである。STSC とはストリーマ放電箱の気体中に荷電粒子によって生ずるガス・シン チレーションを光電子増倍管により検出し，ての出力パルスによってストリーマ放電箱を㗢作させるもの である。換言すれば同一の装置を，最初ガス・シンチレーション計数管として働かせ，その次にはストリ 一マ放電箱として働作させる仕掛けになっている。との装置の開発は数年前京大高エネルギーグループで 開発した自己作働型放電箱の発展した形態として，ストリーマ放電箱の，低エネルギー核実験への応用を 意図していると同時に，低エネルギー分野の新型の飛跡测定器としての可能性を試すために行なわれた。

そもそもストリーマ放電箱之は通常の放電箱がスパーク放電を利用しているのに対してその初期段階で ある“ストリーマ放電”を用いているものであって，放電箱気体中の荷電䊉子通過を外部においた計数管 によって知り，その出力パルスをトリガーパルスしして充分持続時間の短い高電圧パルスを気体に印加し て荷電粒子の飛跡に沿って短いストリーマの列を作らせ，乙れを写真撮影して飛跡を测定する装置であっ て1963年頃ソビエトで発明され，宇宙線や高エネルギー物理の研究分野における有力な測定器として登場 してきたものである。

しかし乍ら，このストリーマ放電箱を低エネルギー核物理の研究に用いた例は，ほんの一，二例の特殊 な場合を除いては皆無であった。この理由は主として低エネルギー粒子は放電箱の壁を通過できないため 外部の計数管群によるトリガリングが不可能になるためである。

低エネルギー核反応の研究において終状態が 3 体以上の場合には，カウンター実験によるよりも飛跡測 定装置による方が望ましい。そして従来の霧箱や写真乾板の性能には大きな制約があるため何か新しい测 定器の出現が侍望されている状況である。てれに対して申請者は STSC の開発を行なったわけである。

本装置を開発するに当って申請者は；1)ヘリウムを用いたガス・シンチレーション計数装置の研究， 2) ガス・シンチレーション・パルスによる Self-triggering の研究，3）ネオンを用いたストリーマ放 
電箱の研究，4）STSCに適した気体（又は混合気体）の探索，5）STSCの働作テスト；の順で段階 的に研究を進めて行った。

STSC の成否は 2 つの機能一ガス・シンチレーション計数管とストリーマ放電箱一を満足する気体を如 何に見つけるか（或は作りだすか）にあるといってよい。申請者はての点について次のような推諭・考察 を行なった。先ず普通ストリーマ放電箱用の気体としては純ネオンが用いられるが，とのネオンのガス・ シンチレーションは通常の光電子增倍管では殆んど検出できない位, 長波長の光である。他方へリウム・ ガス・シンチレーション計数装置の研究において申請者は少量の窒素ガスが波長遷移㨈として有効に働い て純ヘリウムからの短波長のシンチレーションを, 通常の光電子増倍管の感度波長域内の光に変えると之 を経験した。そこでネオンに少量の窒素ガスを混ぜると望ましい STSC 用の混合気体が得られるかも知 れないと推論したわけである。申請者は以上の考察から，ネオンに対し窒素の混合比を変えてポロニウム の $\alpha$ 粒子によるガス・シンチレーション・パルスの波高值の変化を测定してみた。予想通り波高の相対值 は窒素の混合比の $0 \%$ 加急激に上䊬して $0.5 \%$ 付近で極大となり，その後は漱次下降してゆくという結 果が得られた。

次にはこの混合比の気体によって良質のストリーマ放電の飛跡が得られるかどうかが問題である。これ については申請者は，上記の 5 ) に進み，むし 自己作働装置がないならば数百回乃至 1 千回の randomtriggering に対して 1 度位の割合でしか $\alpha$ 粒子の飛跡写真がとれない程度に弱い $\alpha$ 線源を用いて, STSC の全般的な働作テストを行なった。結果は殆んど毎回の Self-triggering に対して $\alpha$ 粒子の飛跡が得られ た。この事実は自己作働装置の成功を示すと共に，上述の混合気体（ネオン $99.5 \%$ +窒素0.5\%) が STSC に適したものであるととを立証している。

以上述べた通り本論文の研究によって申請者は自己作働型ストリーマ放電箱（略称 STSC）を開発・完 成させた。尚，実際にこの装置を核反応の実験に用いた場合に必要な種々の考察と示唆も本論文中に述べ られているととを附言しておく。

\section{論文審 查の結果の要旨}

低エネルギー原子核実験の分野における飛跡測定器はこの10数年来次の三つ一膨脹型霧箱, 拡散型霧箱 及び原子核乾板一に限定されてきたと云える。他方高エネルギー物理学の分野ではこの10数年の間に泡箱 と放電箱が発明され，乙れら二つの測定器の性能が高エネルギー物理の実験に著しく適しているため上述 の二種類の霧箱や乾板に完全によって代ってしまった状況である。

しかしながら泡箱はその高い阻止能のため低エネルギーの実験には不向きであり，又，放電箱も高エネ ルギーの実験に普通用いられている構造のものでは低エネルギー粒子の検出には不適当であるので少数の 例外をのぞいては両者ともに低エネルギー分野においては㱠んど用いられていない。

一般的に核反応においてその終状態が 3 体以上になる場合にはカウンターによるよりも適当な飛跡測定 装置による方が精密な研究が可能である。軽い核のクラスター構造を低エネルギー核反応によって調べよ うとするときや，高エネルギー核反応の一般的機構を調べようとする場合には上述のように終状態が多体 となることが多い。とのような場合に有用な飛跡測定器の出現が長い間望まれていたわけである。 
本申請論文はこの問題に対する一つの解答を与えたものと云い得る。即ち阻止能の低い気体中の荷電粒 子の飛跡を三次元的にストリーマ放電の列として捉えるてとのできるストリーマ放電箱に対して，自己ト リガリング装置 (自己作働装置) を附加して低エネルギー粒子検出に適した飛跡測定器として自己作働型 ストリーマ放電箱（STSC と略す）という新型を創りあげたわけであって，てれは世界的に最初の試みで ある。

次にての STSC を冒頭に述べた 3 種類の装置と比較してみよう。先ず膨脹型霧箱と比べると両者とも に外部トリガリングは可能であるが霧箱の方は内部トリガリングはかなり困難である。しかし，たとえ霧 箱の内部トリガリングが可能と仮定しても湘定器としての 回復時間に両者の間に大きな差異があり， STSC の方が圧倒的に（約 100倍以上）優れている。これはとりも直さず測定器の有効働作時間にこれだ けの差があるということである。次に拡散型霧箱と比較すると，耐えうる放射線の量において STSC は ずっ之優れている。又，拡散霧箱の内部トリガリングは相当困難であろう。最後に原子核乾板との比較で あるが乾板は高い阻止能，現像による shrinkage 更に fading の現象などのため，低エネルギー 粒子の エネルギー・方向を決める際の誤差が STSC に比べてずっと大きいと考えられる。又，乾板の情報には 時間が全く入らないととはSTSCに比べて大きな欠点である。STSCの優れたもう一つの利点としては， ガス・シンチレーションによる望ましい event の選択性である。との性質によると，例えば光核反応の 研究の際，入射 $\gamma$ 線によるバックグランド電子の括びただしい量にす拘らず，望ましい核反応の生じたよ きだけに装置が自己作働して飛跡を測定することが可能となるであろう。

以上述べたように本論文の研究は原子核実験の分野における新しい型の飛跡測定装置を開発・完成させ たものであり，乙れが従来の装置に比べて種々の優れた性能を有していると考えられるので原子核物理 学・高エネルギー物理学研究に対する寄与は大きいと考える。参考論文はいずれも申請者が原子核物理学 及び高エネルギー物理学の分野において優れた学識と研究能力を有しているととを示している。

よって，本論文は理学博士の学位論文として価值あるものと認める。 